\title{
COOPETITION AS AN EXTERNAL SOURCE FOR DRIVING INNOVATION: RESEARCH FINDINGS FROM AP VOJVODINA
}

\author{
САРАДЫА СА КОНКУРЕНЦИЈОМ КАО ЕКСТЕРНИ ИЗВОР РАЗВОЈА \\ ИНОВАЦИЈА: РЕЗУЛТАТИ ИСТРАЖИВАЊА ИЗ АП ВОЈВОДИНЕ
}

\author{
Dušan Bobera ${ }^{1}$ \\ University of Novi Sad, Faculty of Economics in Subotica \\ Bojan Leković ${ }^{2}$ \\ University of Novi Sad, Faculty of Economics in Subotica \\ Maja Strugar-Jelača ${ }^{3}$ \\ University of Novi Sad, Faculty of Economics in Subotica
}

\begin{abstract}
Сажетак: Предмет овог истраживања представља анализа тренутног стања сарадње са конкуренцијом на територији Аутономне Покрајине Војводине, процењено од стране власника или менацера предузећа. Циљ овог истраживања представља детерминисање односа и нивоа сарадње између пословних организачија као и идентификащија улога образовања власника или менаиера предузећа као основа за идентификацију потениијалне вредности овог пословног концепта. Ниво сарадње са конкурениијом истражен је у оквиру узорка од 200 малих и средњих предузећа на територији Аутономне Покрајине Војводине. Резултати аналлиза указују на позитивну оцену сарадње са конкуренцијом у посматраном узорку. Такође, виши нивои образовања утичу на значајну идентификацију сарадње са конкуренцијом као екстерним извором развоја иновација. Ово истраживање од значаја је власницима или менацерима предузећа приликом разумевања и усвајања конщепта сарадње са конкурениијом као алатом за развој иноваџија путем трансформащије посматрања конкуренције као непријательког пословног елемента.
\end{abstract}

Кључне речи: иновације, сарадња, конкуренција,

Abstract: Subject of this research represents analysis of current state of cooperation with competition (coopetition) in the Autonomous Province of Vojvodina, Republic of Serbia, estimated by owner or manager of enterprises. The aim of the research is to determine relations and level of cooperation between business organizations as well as identifying role of owners or managers education as a basis for identification of potential value of coopetition concept. The level of cooperation with competition was explored in the sample of 200 small business organizations from the Autonomous Province of Vojvodina. The results indicate a positive estimation of owners or managers regarding the cooperation with competition in the observed sample. Also, higher level of education has influenced on significant identification of coopetition as an external source for driving innovation. This study helps owners or managers to understand and adopt coopetition concept as a tool for pursuing opportunities by transforming currently observation of competitors as a hostile business element.

\footnotetext{
${ }^{1}$ bobera@ef.uns.ac.rs

2 bojan.lekovic@ef.uns.ac.rs

3 majas@ef.uns.ac.rs
} 
Keywords: innovation, cooperation, competition

\section{INTRODUCTION}

Small businesses have limited resources. Their potential for growth is dominantly external located. Regardless of high level of flexibility on the market, speed of reaction, and high innovativeness of small businesses, lack of resources is their main developmental restrain and factor of survival. Traditional understanding of the competition leads to the main obstacle in finding lacking resources among external partners. Cooperation with the competition decreases expenses but moreover it provides lacking knowledge and complementary resources.

This research paper is focused on: identification and defining influences of co-opetition, as a business framework; then on the positive effects for the participants in this process, recognized by all the actors involved in the concept; and also on the level of achieved development in implementing this business concept embodied in the attitude towards cooperation as business relationship with the competition.

Small businesses as a field of research has so many specifics, firstly in a space for innovation development. They have a tendency to innovate but lack of resources to implement those innovation projects. So making coopetition effective is especially important for small businesses in order to overcome the lack of resources among these organizations.

\section{THEORETICAL BACKGROUND}

Drucker suggests that innovation is primary activity of entrepreneurial thinking, regarding innovation as a process by which entrepreneurs convert ideas into marketable opportunities (Drucker, 1985). Same author also defines innovation as a specific function of entrepreneurial business, it is a process which enable entrepreneur to create new wealth - producing resources or endows existing resources with enhanced potential for creating wealth (Drucker, 2002). Therefore, it has become essential for an organization to adapt, develop and innovate in order to achieve a competitive advantage and become successful (Hassanien \& Crisp' 2012). Achievement of a long - term business success is reflected in profitability and sustainable growth. However, profitability is directly related to innovation. Innovation is a welldeveloped and extensively examined area of management, since it is widely identified as the basic development and competitiveness factor, with increasing importance in the age of knowledge-driven economy (Stošić, 2012). 
Innovative activities related to cooperation with external factors, provide space for outsourcing of business possibilities and resources which are not available inside organization. This includes possibilities of efficient knowledge transfer, exchange of resources and organizational learning. Assembling these forms of cooperation in research and development area, puts aside competitive confrontation at the market. This provides a stable and comprehensive customization of missing resources. After that, complementary assets and resources can combine and consolidate in order to achieve a synergetic effect.

Nature of the innovative activities depends on many factors. First group is related to the specifics of the organization, in terms of intensity of innovation activities, size of the organization and its resource capabilities. The second group includes environmental factors such as availability of external resources, market structure, technological level of industry, etc. (Flaig \& Stadler,1998; Kleinknecht, 1996; Martin, 1994). Finally, the dilemma of providing technological capacity based on their own efforts or through cooperation with the environment, represents decision of organization whose business is largely dependent on research and development activities. Therefore, entrepreneurial activities are focused on the adoption of open innovation concept with aim of finding lacking resources outside of their organization. Consequently, concept of open innovation has been given its importance in recent years, which have been addressed by many authors (Alguzeaui \& Filieri, 2010; Enkel et.al, 2010; Vrande et.al., 2009). As one of the environment element and a potential partner in the process of advancing innovative ventures, the role of competitors can be emphasized. Some authors (Becker \& Peters, 1998; Robertson \& Langlois, 1995) have named common funding, cost saving, realization of the economy of the extent, and reducing degree of uncertainty as main benefits of coopetition. However, as the main drawback of this business concept referred to an increase in transaction costs incurred as a result of the necessary coordination. Also, different practices of organizations involved in cooperation, may affect the difficulty in the management and control activities. Development and expansion of the innovative activities become very important strategic orientation. Therefore, according to research of collaboration influence by Gnyawali \& Park (2011), coopetition capabilities of firms play an important role in enhancing common benefits as well as in gaining proportionately larger share of the benefits.

Sustainable growth generated by continuous innovation is based upon the capabilities and attitudes of the people within the organization, and depends on a culture that encourages entrepreneurship and processes which enable individual and team - based creativity to surface and 
flourish (Knox, 2002). Innovation could be considered as a result of a common effort of several participants. The phenomenon of coopetition, that is, simultaneous cooperation and competition between enterprises, has become increasingly popular in recent years (Ketchen et.al., 2004). This concept becomes important after its successful implementation in practice (Walley, 2007). Coopetition occurs when two firms cooperate in some business activities while simultaneously competing with one another (Luo, 2005). Cooperation with competition is defined as a strategy of embodying simultaneous cooperation (Bengtsson \& Kock, 2000) and competition between organizations (Gnyawali \& Byung-Jin, 2009). Cassiman et.al (2009) feels that balancing co-operative and competitive forces in the innovation process to co-create value and to capture part of this value has become crucial to profit from innovation. Same author finds, that competitive forces may prevail when value capture is zero and cooperation forces may prevail in the value creation phase. The behavior of the participants in the process of coopetition is recognized by the authors Lavie (2007), Ritala \& Hurmelinna-Laukkanen (2009). They point out that the participants are facing the dilemma of joint participation in the process of value creation and temptations in appropriating the greater part of the newly created value. They emphasize dilemma that occurred for those actors during producing and later equal or proportional sharing of the produced value. Cooperation between competitive enterprises by gathering the assets, technologies and knowledge can speed up and facilitate the process of a new product creation. Coopetition is more critical in high technology contexts because of several challenges, such as shrinking product life cycles, greater investments in research and development, convergence of multiple technologies, and importance of technological standards (Gnyawali \& Park, 2009). Competitive organizations have relevant and complementary resources and challenges, such as market and technological requirements, so cooperation with the competition enables the creation and application of new knowledge at favorable conditions in order to generate innovation (Ritala et al., 2009). Definitely, coopetition as a business framework is compromise between collaboration and competition (Chen, 2008) and represents specific strategy with synergy results (Bengtsson \& Kock, 2000). The growing popularity of this concept is also reflected in the fact that $50 \%$ of all forms of cooperation within strategic business alliances between competitors is present within the same industry (Harbison \& Pekar, 1998). Coopetition can be seen as a collection of different types of relationships, where competitive and cooperative forces are precisely delimited between the involved parties (Bengtsson et al., 2010). 
In the long term, innovation is treated as a significant source of competitive advantage. Thus, cooperation between competitors constitutes timely access to knowledge and resources that are not otherwise available, enabling the implementation of specific innovation projects at significant risk and extent of investment. The above mentioned positions are in accordance with Sampson (2007), who believes that through cooperation with competitors, participants acquire new knowledge and skills in order to enhance their innovation outcomes. Main motive of development and implementation of the new business concept is the expected result of cooperation. Created and maintained value, as a result of joint efforts, represents the primary result of the cooperation of the participants. The individual benefits of each participant are conditioned by dividing effects that are often found outside the boundaries of cooperation.

Cooperation results in numerous immeasurable benefits simultaneously, participants in cooperation are prepared for all possible negative consequences that may arise (Tsai, 2002). Negative consequence of the cooperation is a potential conflict between the participants. Since all the participants of this concept are oriented on the appropriation of the maximum effects of cooperation, undefined relations of cooperation can have undesirable outcomes. From the standpoint of the national economy, this form of cooperation between the leading competitors in a given area has far-reaching positive effects on the improvement of economic activities. Consequently, coopetition concept gets increasingly important for policy makers. Innovative degree of national economy and economic development can be partly attributed to the intensity of cooperation between competitors. Previous assertion is confirmed by the survey Miles et.al. (2005), who also define cooperation with competition as a process where two or more parties work closely in order to achieve mutually beneficial outcomes (Miles et al. 2006).

Observed as separate units, cooperation and competition offer only segments of the business reality. Business success requires the simultaneous implementation of both of these strategies. In this way, coopetion as a strategy is becoming increasingly important, since it plays a crucial role in business performance and survival of a company which is especially important for the segment such as small businesses. 


\section{RESEARCH METHODOLOGY}

\subsection{SAMPLE AND DATA}

According to available data of the Agency for Economic Registers, 2603 enterprises have been classified into small businesses. The sample used for researching has characteristics of a proportional stratified sample. Most sample proportions in relation to the basic set amounts to 0.10 , i.e. 200 small businesses. Stratification has been done based on regions in order to represent adequately the basic set from the spatial aspect. Table 1 gives a descriptive statistics of the sample based on the gender, age, education and experiences of respondents.

Table 1.: Descriptive statistics - gender, age, education, experience

$(\mathrm{N}=\mathbf{2 0 0})$

\begin{tabular}{|c|c|c|c|}
\hline Gender & Frequency & Valid Percent & Cumulative Percent \\
\hline Male & 110 & 55.0 & 55.0 \\
\hline Female & 90 & 45.0 & 100.0 \\
\hline Total & 200 & 100.0 & \\
\hline Age & Frequency & Valid Percent & Cumulative Percent \\
\hline$\leq 40$ & 145 & 72.5 & 72.5 \\
\hline$\geq 41$ & 55 & 27.5 & 100.0 \\
\hline Total & 200 & 100,0 & \\
\hline Education & Frequency & Valid Percent & Cumulative Percent \\
\hline High school & 24 & 12.0 & 12.0 \\
\hline Higher school (College) & 36 & 18.0 & 30.0 \\
\hline Bachelor & 100 & 50.0 & 80.0 \\
\hline Master & 39 & 19.5 & 99.5 \\
\hline $\mathrm{PhD}$ & 1 & .5 & 100.0 \\
\hline Total & 200 & 100,0 & \\
\hline Years of existence & Frequency & Valid Percent & Cumulative Percent \\
\hline $0-3$ years & 10 & 5.0 & 5.0 \\
\hline $3-5$ & 10 & 5.0 & 10.0 \\
\hline $5-7$ & 2 & 1.0 & 11.0 \\
\hline $7-10$ & 21 & 10.5 & 21.5 \\
\hline $10+$ & 157 & 78.5 & 100.0 \\
\hline Total & 200 & 100,0 & \\
\hline
\end{tabular}

Online questionnaire was used to identify awareness of cooperation with competition among entrepreneurs/owners/mangers in the Autonomuous Province of Vojvodina. The questionnaire consisting of 20 questions, based on Likert spectrum in interval from 1 to 6 points, was designed in Google questionnaire. Entrepreneurs gave their responses to 20 questions, by marking one of the offered responses. The questionnaire was distributed to entrepreneurs, business owners over the internet via email. The survey was exploring current level of open innovation concept 
among entrepreneurs/owners/managers from the aspect of age, gender, education and entrepreneurial venture maturity. Selected variables for analyzing the research problem in this paper represent a part of conducted research in the field of open innovation. Beside cooperation with Universities, cooperation with customers and cooperation with suppliers, authors of this paper have decided to observe cooperation with competition as a rising research problem in the field of innovation management in the Autonomous Province of Vojvodina, Republic of Serbia. Variables used in the research were:

- Var.CC_01 (Competition contribution) - how respondents perceive scope and significance of the impact of competition on the innovation development (product or service),

- Var.LC_O2 (Level of cooperation) - how respondents perceive the current level of cooperation achieved with the competition in the innovation development (product or service),

- Var.CP_03 (Cooperation period) - duration of the cooperation with the competition in the function of innovation development (product or service),

- Var.CO_04 (Cooperation output) - satisfaction with the result of cooperation with the competition in the form of a new product / service,

- Var.IFA_05 (Influence of financial assets) - impact of the financial resource availability on the innovation development of new products/services in cooperation with the competition.

The sample was analyzed in three steps: the authors have made and presented descriptive statistics of the sample; second, the sample was analyzed with Spearman correlation coefficient; third, sample was also analyzed with Kruskal Wallis and Mann Whitney U test. The questionnaire was distributed by e-mail to 370 entrepreneurs/owners/managers and was filled by 200 respondents. The rate of response was $54.05 \%$. Data analysis was performed through SPSS program for statistical analysis, version 20.

\subsection{HYPOTHESES AND METHODOLOGY}

Taking into consideration the research intention, which is the result of precisely defined areas of research, research suppositions in the form of hypotheses have been set:

H1: There is positive correlations between owner / entrepreneur / manager's estimation on competition contribution, level of cooperation, cooperation period, cooperation output and influence on financial assets.

Vol. 19, бpoj 1/2017, cmp. 1-16 
Hla: There is positive correlations between owner / entrepreneur / manager's estimation on level of cooperation and Cooperation period, Cooperation output, Influence of financial assets.

H1b: There is positive correlations between owner / entrepreneur / manager's estimation on cooperation period and cooperation output.

H1c: There is positive correlations between owner / entrepreneur / manager's estimation on cooperation output and influence of financial assets.

H2: There is difference between owner / entrepreneur / manager's estimation, according to their level of education, in term of competition contribution, level of cooperation and influence of financial assets.

Data collected sample was analyzed using two statistical methods. For researching the connectivity of selected constant variables Spearman's rho correlation was used. Correlation indicates direction (positive or negative) and strength of connection of observed variables. In order to identify and determine differences between the identified groups, Kruskal Wallis and Mann Whitney U test were used. Selected statistical analysis was performed with the intention of determining statistically significant differences between groups of examinees, categorized according to their level of education, with assumption that higher levels of education implies significant perception of cooperation with competitors as a possibility for the innovation development.

\section{RESULTS OF THE ANALYSIS}

The first step in the analysis involves testing connectivity of selected research variables in terms of the strength and direction of the connection. This analysis enables identification and definition of the copetition impact on participants, in terms of positive effects recognized by the actors involved in the concept. Also, according to respondent's estimation, it indicates level of utilization of this business concept.

Link between the level of cooperation (Var.LC_02) and competition contribution (Var.CC_01) is expressed by Spearman's correlation coefficient. Positive correlation of very weak between the intensity of these two variables was found, $\mathrm{r}=.177, \mathrm{n}=200, \mathrm{p}<.012$. Whereby a higher degree of competition contribution (Var.CC_01) implies a higher degree of level of cooperation (Var.LC_02).

The link between the level of cooperation (Var.LC_02) and the cooperation period (Var.CP_03) was expressed by the Spearman's correlation coefficient. Positive correlation of weak intensity between these two variables was found, $\mathrm{r}=.376, \mathrm{n}=200, \mathrm{p}<.000$. Whereby a higher degree of level of cooperation (Var.LC_02) implies cooperation during longer period (Var.CP_03).

The link between the level of cooperation (Var.LC_02) and cooperation output (Var.CO_04) was expressed by the Spearman's correlation coefficient. Positive correlation of weak intensity between these two variables was found, $\mathrm{r}=.315, \mathrm{n}=200, \mathrm{p}<.000$. Whereby a 
higher degree of level of cooperation (Var.LC_02) implies greater satisfaction with the cooperation output (Var.CO_04).

The link between the level of cooperation (Var.LC_02) and the influence of financial factors (Var.IFF_05) was expressed by the Spearman's correlation coefficient. Positive correlation of very weak intensity between these two variables was found, $r=.190, n=200, p$ $<0.007$. Whereby a higher degree of level of cooperation (Var.LC_02) implies significant financial impact factors (Var.CO_04).

The link between cooperation period (Var.CP_03) and cooperation output (Var.CO_04) was expressed by the Spearman's correlation coefficient. Positive correlation of weak intensity between these two variables was found, $\mathrm{r}=.242, \mathrm{n}=200, \mathrm{p}<.001$, where in a longer period of cooperation (Var.CP_03) includes a more significant cooperation period (Var.CP_03).

Table 2.: Spearman's rho correlation coefficient - mutual correlation between selected variables

\begin{tabular}{|c|c|c|c|c|c|c|c|}
\hline \multicolumn{8}{|c|}{ Correlations } \\
\hline & & & $\begin{array}{c}\text { Var.CC } \\
-01\end{array}$ & $\begin{array}{c}\text { Var.LC } \\
\quad 02\end{array}$ & $\begin{array}{c}\text { Var.CP } \\
\quad 03\end{array}$ & $\begin{array}{c}\text { Var.CO } \\
-04\end{array}$ & $\begin{array}{c}\text { Var.IFA } \\
\ldots 05\end{array}$ \\
\hline \multirow{5}{*}{ 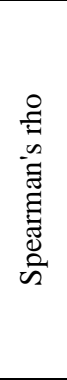 } & Var.CC_01 & $\begin{array}{l}\text { Correlation } \\
\text { Coefficient }\end{array}$ & 1 & & & & \\
\hline & Var.LC_02 & $\begin{array}{l}\text { Correlation } \\
\text { Coefficient }\end{array}$ & $.177^{*}$ & 1 & & & \\
\hline & Var.CP_03 & $\begin{array}{l}\text { Correlation } \\
\text { Coefficient }\end{array}$ & .114 & $.376^{* *}$ & 1 & & \\
\hline & Var.CO_04 & $\begin{array}{l}\text { Correlation } \\
\text { Coefficient }\end{array}$ & .069 & $.315^{* *}$ & $.242^{* * *}$ & 1 & \\
\hline & Var.IFA_05 & $\begin{array}{l}\text { Correlation } \\
\text { Coefficient }\end{array}$ & -.042 & $.190^{* * *}$ & .023 & $.338^{* * *}$ & 1 \\
\hline & ation is sis & ant at the 0 . & $\begin{array}{l}\text { vel (2-ta } \\
\text { evel (2-t }\end{array}$ & $\begin{array}{l}\text { d). } \\
\text { ed) }\end{array}$ & & & \\
\hline
\end{tabular}

\section{Source: Author's calculation}

The link between cooperation output (Var.CO_04) and the influence of financial factors (Var.IFA_05) was expressed by the Spearman's correlation coefficient. Positive correlation of weak intensity between these two variables was found, $\mathrm{r}=.338, \mathrm{n}=200, \mathrm{p}<.000$, where significant cooperation output (Var.CO_04) implies significant influence of financial factors (Var.IFF_05).

Identification of potential external resources for the development of innovation, particularly in the form of cooperation with the competition, is determined by the level of education. Therefore, the basic motive of the authors in a further analysis, will represent identifying 
differences between groups with different levels of education, according to the scope and structure of established cooperation with competition. For the purposes of this test research intentions, authors have decided to use statistical analysis Kruskal Wallis and Mann Whitney test. Before mentioned methods were applied in order to identify significant differences between different groups of respondents, classified by level of education. In order to facilitate transparency and visibility of the obtained results, only variables with statistically significant differences were depicted.

Table 3.: Kruskal Wallis $H$ and Man Whitney $U$ test - level of education

\begin{tabular}{|c|c|c|c|c|c|c|c|}
\hline \multicolumn{6}{|c|}{ Kruskal Wallis test } & \multicolumn{2}{|c|}{ Mann Whitney U test } \\
\hline \multirow[t]{2}{*}{ Variable } & \multicolumn{4}{|c|}{ Level of education } & \multirow[t]{2}{*}{$\begin{array}{c}\text { p - } \\
\text { value }\end{array}$} & & \multirow[t]{2}{*}{$\begin{array}{c}\mathrm{p}- \\
\text { value } \\
<.008\end{array}$} \\
\hline & $\begin{array}{c}\text { High } \\
\text { school } \\
\text { degree } \\
(\mathrm{N}=\mathbf{2 4})\end{array}$ & $\begin{array}{c}\text { Higher } \\
\text { school } \\
\text { degree } \\
(\mathrm{N}=36)\end{array}$ & $\begin{array}{c}\text { Faculty } \\
(\mathbf{N}= \\
100)\end{array}$ & $\begin{array}{c}\text { Master } \\
\text { degree } \\
(\mathrm{N}=40)\end{array}$ & & $\begin{array}{l}\text { Pair wise } \\
\text { comparison }\end{array}$ & \\
\hline $\begin{array}{c}\text { Var.CC } \\
\ldots 01\end{array}$ & $\begin{array}{l}87.42 \\
2.00\end{array}$ & $\begin{array}{c}85.44 \\
2.00\end{array}$ & $\begin{array}{l}100.03 \\
3.00\end{array}$ & $\begin{array}{c}123.09 \\
3.50\end{array}$ & .017 & $\begin{array}{c}\text { Higher school degree } \\
<\text { Master degree * }\end{array}$ & .003 \\
\hline $\begin{array}{c}\text { Var.LC } \\
\_02\end{array}$ & $\begin{array}{c}101.52 \\
3.00\end{array}$ & $\begin{array}{l}84.47 \\
2.00\end{array}$ & $\begin{array}{l}97.43 \\
2.00\end{array}$ & $\begin{array}{c}121.99 \\
3.00\end{array}$ & .027 & $\begin{array}{c}\text { Higher school degree } \\
<\text { Master degree * }\end{array}$ & .006 \\
\hline \multirow[t]{3}{*}{$\begin{array}{c}\text { Var.IFA } \\
\text { 05 }\end{array}$} & $\begin{array}{c}119.04 \\
3.00\end{array}$ & $\begin{array}{l}82.61 ; \\
2.00\end{array}$ & $\begin{array}{c}93.27 \\
2,00\end{array}$ & $\begin{array}{c}123.55 \\
3.00\end{array}$ & .002 & $\begin{array}{l}\text { Higher school degree } \\
<\text { Master degree * }\end{array}$ & .001 \\
\hline & & & & & & $\begin{array}{c}\text { Faculty }<\text { Master } \\
\text { degree * }\end{array}$ & .005 \\
\hline & & & & & & $\begin{array}{c}\text { Higher school degree } \\
<\text { High school } *\end{array}$ & .007 \\
\hline
\end{tabular}

Source: Author's calculation

Kruskal Wallis $\mathrm{H}$ test showed significant statistical difference between four groups of examinees, according to their level of education (Gp1, n=24: High school degree; Gp2, n=36: Higher school degree; Gp3, $\mathrm{n}=100$, Faculty; Gp4, $\mathrm{n}=40$, Master degree). Significant statistical difference has been found within following observed variables:

- Competition contribution, $\mathrm{c}^{2}(3,200)=10.241, \mathrm{p}=.017$

- Level of cooperation, $\mathrm{c}^{2}(3,200)=9.170, \mathrm{p}=.027$

- Influence of financial assets, $\mathrm{c}^{2}(3,200)=14.971, \mathrm{p}=.002$

Kruskal Wallis $\mathrm{H}$ test has revealed statistically significant differences in the observed variables, however, on the basis of this test, it is not obvious and precise mentioned which group is statistically different. In order to determine statistically significant differences between the groups Mann Whitney U test was used. During the pair wise comparison, Bonferroni correction was applied to the alpha values. 
Bonferroni adjustment means sharing alpha values with number of tests carried out, thus revised alfa level is used as a criterion for determining significance. In this case, stricter alfa value is $0.05 / 6=0.008$.

Mann-Whitney $U$ test revealed a significant difference in perception of Competition contribution (Var.CC_O1) between examinees with acquired higher school degree $(\mathrm{Md}=2, \mathrm{n}=36)$ and examinees with acquired master's degree $(\mathrm{Md}=3.5, \mathrm{n}=40), \mathrm{U}=446, \mathrm{z}=-2.928, \mathrm{p}=.003, \mathrm{r}=$ .008 . The real difference between the mean values of the groups is at the level of small significance. The magnitude of this difference is expressed by the use of $r$ - value. Subsequent comparison showed that category of examinees with acquired master's degree $(M=45.35)$ are significantly different from the group of those with acquired higher school degree $(\mathrm{M}=30.89)$.

Mann-Whitney $U$ test revealed a significant difference in perception of Level of cooperation (Var.LC_O2) between examinees with acquired higher school degree $(\mathrm{Md}=2, \mathrm{n}=36)$ and examinees with acquired master's degree $(\mathrm{Md}=3, \mathrm{n}=40), \mathrm{U}=462, \mathrm{z}=-2.79, \mathrm{p}=.006, \mathrm{r}=$ .019. The real difference between the mean values of the groups is at the level of small significance. The magnitude of this difference is expressed by the use of $r$ - value. Subsequent comparison showed that category of examinees with acquired master's degree $(M=44.95)$ are significantly different from the group of those with acquired higher school degree $(\mathrm{M}=31.33)$.

Mann-Whitney $U$ test revealed a significant difference in perception of Influence of financial assets (Var.IFA_05) between examinees with acquired higher school degree $(\mathrm{Md}=2, \mathrm{n}=36)$ and examinees with acquired master's degree $(\mathrm{Md}=3, \mathrm{n}=40), \mathrm{U}=400.5, \mathrm{z}=$ $3.441, p=.001, r=.243$. The real difference between the mean values of the groups is at the level of small significance. The magnitude of this difference is expressed by the use of $r$ - value. Subsequent comparison showed that category of examinees with acquired master's degree $(M=46.49)$ are significantly different from the group of those with acquired higher school degree ( $M=29.63)$.

Mann-Whitney $U$ test revealed a significant difference in perception of Influence of financial assets (Var.IFA_05) between examinees with acquired Faculty degree $(\mathrm{Md}=2, \mathrm{n}=100)$ and examinees with acquired master's degree $(\mathrm{Md}=3, \mathrm{n}=40), \mathrm{U}=1418, \mathrm{z}=-2.778, \mathrm{p}=$ $.005, \mathrm{r}=.196$. The real difference between the mean values of the groups is at the level of small significance. The magnitude of this difference is expressed by the use of $\mathrm{r}$ - value. Subsequent comparison showed that category of examinees with acquired master's degree $(M=85.05)$ are 
significantly different from the group of those with acquired Faculty degree $(M=64.68)$.

Mann-Whitney $U$ test revealed a significant difference in perception of Influence of financial assets (Var.IFA_05) between examinees with acquired higher school degree $(\mathrm{Md}=2, \mathrm{n}=36)$ and examinees with acquired high school degree $(M d=3, n=24), U=260.5, z=$ $-2.695, \mathrm{p}=.007, \mathrm{r}=.191$. The real difference between the mean values of the groups is at the level of small significance. The magnitude of this difference is expressed by the use of $r$ - value. Subsequent comparison showed that category of examinees with acquired higher school degree $(M=25.74)$ are significantly different from the group of those with acquired high school degree $(M=37.65)$.

\section{DISCUSSION AND CONCLUSION}

Based on conducted statistical analysis, authors of this paper came up with the following results. Using the Spearman correlation test hypothesis $\mathrm{H} 1$ was confirmed. There are statistically significant positive correlations between owner/entrepreneur/manager's estimations on competition contribution, level of cooperation, cooperation period, cooperation output and influence on financial assets. Hypothesis H1 was confirmed through the confirmation of developed sub-hypothesis H1a, $\mathrm{H} 1 \mathrm{~b}$ and H1c. Hypothesis $\mathrm{H} 2$ was confirmed since authors found statistically significant positive correlations between owner/entrepreneur/manager's estimation on competition contribution, level of cooperation and influence of financial assets.

Coopetition concept, includes cooperation in order to develop innovations that require certain research and development activities. Therefore, the larger allocation of financial resources, a longer period for prototype development, product commercialization, are a logical consequence of the inevitable companion of this process. Because of the necessary knowledge for the startup process of research and development projects, characteristic of this concept is the participation of highly educated individuals. They are familiar with the advantages and disadvantages of this concept, as well as its process. They also have the knowledge and skills in the field where they launch innovative projects. Also, people with higher levels of education have established contacts and the level of cooperation with academic and research community. The result of this cooperation occurs in the form of new knowledge beneficial to the development of new products.

This work contributes to the stakeholders in terms of indicating the potential of coopetition concept. Improved theoretical body, 
conducted research, its results, forms the basis for decision-making process improvement. First of all, these are the owners / managers / entrepreneurs whose decision depends mostly on the ability to start cooperation with the competition. This study tries to show not only the necessity of cooperation between the economic participants, but also to adopt set of values of this concept, as well as a proactive approach in perceiving environment and recognition of cooperative potential in the environment. Successful implementation of this concept and its sustainability, lies in the possibility of participant to balance their cooperative and competitive forces, during the period of cooperation. Second group of stakeholders can be recognized as a policy-makers that would further acknowledge the existence of this concept and unambiguously support it by creating a policy in the development of the innovative capacity of national economies, taking into account the encouraging cooperative capacities of commercial participants simultaneously regulating protection participant interests in the field of intellectual property. Therefore, this study should trigger further research in this area with the aim of emphasizing importance of this concept and its effect on the improvement of innovative performance of enterprises and the overall national economy.

Also, research gained insight into the current state of cooperation with the competition on a sample of two hundred respondents in the Autonomous Province of Vojvodina. While there is a possibility of relativizing the significance of the sample, there is a need to emphasize this kind of research as one of the first in the still insufficient research area. Potential limitations of sample size or territorial coverage of research opens up opportunities to expand this study by including countries in the region. Currently, based on the same questionnaires, research is conducted, on the territory of the Republic of Montenegro, with the aim of obtaining information that would allow comparative analysis of open innovation concept.

Additional limitation of research, refers to sample structure, which included only small enterprises in the Autonomous Province of Vojvodina, Republic of Serbia. Future research could include entrepreneurial ventures which are in the incubation period, considering innovation development as an entrepreneur's aspiration, which leads to mature stages of entrepreneurial ventures.

The research is based on the observation and analysis of current data, which can be also considered as a limitation of this research. Because, obtained results indicates certain phenomena without changes in its environment. Research based on longitudinal data would enable consideration of the specified time period, which would allow a more 
precise interpretation of research results and defining future potential trends. Time series data, could be provided by the continuous annual surveys. Creating a database that would enable time series analysis would contribute to the possibilities of the precise predictions and forecasting of future trends of the observed phenomenon.

This research, published in the form of a scientific paper, provides multiple benefits. First of all, enhanced and upgraded the existing literature in the field of open innovation, which indicates the need for rejection of traditional understanding of competition as inhospitable and hostile element in the environment. Theoretical material and the obtained results indicated the need for a transitory process in the perception of the business environment. Because, economy of the Republic of Serbia requires the involvement of all potential resources, in the function of building and strengthening the innovative capacity of the national economy, with the ultimate aim of achieving economic development. The ability to overcome the constraints, in the form of disposal inadequate and insufficient resources for the development of innovation, has been recognized in conjunction with the competition, based on the satisfaction of all participants in the process.

\section{LITERATURE}

1. Alguezaui, S., Filieri, R. (2010). Investigating the role of social capital in innovation: sparse versus dense network. Journal of knowledge management, 14(6), 891-909.

2. Becker, W., Peters, J. (1998). R\&D-competition between vertical corporate networks: Market structure and strategic R\&Dspillovers. Economics of Innovation and New Technology, 6(1), 51-72.

3. Bengtsson, M., Kock, S. (2000). Coopetition" in business networks - to cooperate and compete simultaneously. Industrial Marketing Management, 29(5), 411-426.

4. Bengtsson, M., Eriksson, J., Wincent, J. (2010). Coopetition: new ideas for a new paradigm. In: Yami, S., Castaldo, S., Dagnino, G.B., Le Roy, F. (Eds.). Coopetition: Winning Strategies for the 21st Century. Edward Elgar, Northampton, MA, pp. 19-39.

5. Cassiman, B., Di Guardo, M. C., Valentini, G. (2009). Organising $\mathrm{R} \& \mathrm{D}$ projects to profit from innovation: Insights from coopetition. Long Range Planning, 42(2), 216-233.

6. Chen, M.J. (2008). Reconceptualizing the competitioncooperation relationship: a transparadox perspective. Journal of Management Inquiry 17 (4), 288-305. 
7. Enkel, E., Gassmann, O., Chesbrough, H. (2009). Open R\&D and open innovation: exploring the phenomenon. $R \& D$ Management, 39(4), 311-316.

8. Drucker, P. (1985): Entrepreneurship and Innovation: Practice and Principles, New York: HarperBusiness.

9. Drucker P., (2002). The discipline of Innovation, Harward Business Review, 80, 95-104.

10. Flaig, G., Stadler, M. (1998). On the dynamics of product and process innovations-A bivariate random effects probit model (No. 20365). University of Munich, Department of Economics.

11. Gnyawali, D. R., Park, B. J. R. (2011). Coopetition between giants: Collaboration with competitors for technological innovation, Research policy, 40, 650-663.

12. Gnyawali, D. R., Park, B. J. R. (2009). Co-opetition and Technological Innovation in Small and Medium-Sized Enterprises: A Multilevel Conceptual Model. Journal of Small Business Management, 47(3), 308-330;

13. Harbison, J. R., Pekar, P. P., Stasior, W. F. (1998). Smart alliances: A practical guide to repeatable success. San Francisco: Jossey-Bass.Smart Alliances.

14. Hassanien A., Dale C. (2012). Drivers and barriers of new product development and innovation in event venues: A multiple case study, Journal of Facilities Management, 12, 75 - 92.

15. Ketchen, D. J., Snow, C. C., Hoover, V. L. (2004). Research on competitive dynamics: Recent accomplishments and future challenges. Journal of Management, 30(6), 779-804.

16. Kleinknecht, A. (1996). "New indicators and determinants of innovation: An introduction". In Determinants of innovation. The message from new indicators, Edited by: Kleinknecht, A. 112. New York: Macmillan Press.

17. Knox, S. (2002). The boardroom agenda: developing the innovative organisation. Corporate Governance, 2(1), 27-36.

18. Lavie, D., (2007). Alliance portfolios and firm performance: a study of value creation and appropriation in the US software industry. Strategic Management Journal, 28, 1187-1212.

19. Luo, Y. (2005). Toward Coopetition within a Multinational Enterprise: A Perspective from Foreign Subsidiaries., Journal of World Business, 40(1): 71-90.

20. Martin, S. (1994). Industrial economics: Economic analysis and public policy, 2nd Edition. Prentice Hall. 
21. Miles, R.E., Miles G., Snow C.C. (eds) (2005). Collaborative entrepreneurship: how network firms use continuous innovation to create economic wealth. Stanford University Press, Stanford

22. Miles, R.E., Miles, G., Snow, C.C. (2006). Collaborative entrepreneurship: a business model for continuous innovation. Organizational Dynamics, $35(1), \quad 1 \quad-\quad 11$. doi:10.1016/j.orgdyn.2005.12.004

23. Ritala, P., Hurmelinna-Laukkanen, P. (2009). What's in it for me? Creating and appropriating value in innovation-related coopetition. Technovation, 29 (12), 819-828.

24. Robertson, P.L., Langlois, R.N. (1995). Innovation, networks, and vertical integration. Research Policy, 24, 543-562.

25. Sampson, R.C. (2007). R\&D alliances and firm performance: the impact of technological diversity and alliance organization on innovation. The Academy of Management Journal, 50 (2), 364386.

26. Stošić B., Vasiljević, D., Milutinović, R., (2012). The role of patent indicators in innovative performance. Proceedings of the XIII International Symposium SymOrg 2012: Innovative Management and Business Performance, 80-87.

27. Tsai, W.P. (2002). Social structure of "coopetition" within a multiunit organization: coordination, competition, and intraorganizational knowledge sharing. Organization Science, 13 (2), 179-190.

28. Vrande, V., Jong, J., Vanhaverbeke, W., Rochemont, M., (2009). Open Inovation in SME's: Trends, Motives and Management Chalanges, Technovation, 29, 423-437. doi:10.1016/j.technovation.2008.10.001

29. Walley, K., (2007). Coopetition: an introduction to the subject and an agenda for research. International Studies of Management \& Organization, 37 (2), 11- 31. 